\title{
Late mandibular fracture after attempted third molar surgery: case report
}

Fratura mandibular tardia após tentativa de extração de terceiro molar: reporte de caso

Fractura mandibular tardía después de intento de extracción de tercer molar: reporte de caso

Rodrigo Capalbo da SILVA ${ }^{1}$

Henrique HADAD ${ }^{1}$

Jonathas Eduardo Virgilio PIASSI ${ }^{2}$

Luara Teixeira COLOMBO ${ }^{1}$

Bruno Coelho MENDES ${ }^{1}$

Fábio Roberto de Souza BATISTA ${ }^{1}$

Idelmo Rangel GARCIA JÚNIOR ${ }^{1}$

Francisley Ávila SOUZA ${ }^{\mathbf{1}}$

${ }^{I}$ Department of Surgery and Integrated Clinic - São Paulo State University, Araçatuba School of Dentistry, Araçatuba, Brazil.

${ }^{2}$ Federal University of Alfenas - Minas Gerais, Alfenas, Brazil

\begin{abstract}
Removal of lower third molar corresponds to one of the most common procedures in oral surgery. The extraction can result in several intraoperative or postoperative complications, especially when fully impacted molars are involved. This case report describes a mandibular angle fracture following removal of a fully impacted lower third molar of a 41 years old male patient. The fracture occurred 3 days after the attempt to extract the tooth 38 by a dentist surgeon. Several factors influencing the possibility of fracture including gender, age, dental position, and angulation were reviewed and associated with the injury. A fracture line in the angular region of the jaw was observed in radiological and tomographic analysis, both essential to perform the diagnosis. Open reduction internal fixation treatment approach was realized to ensure the best patient's recovery. We conclude that the difficult to maintain a soft diet and the complete dentition factor could have been determinant to cause the fracture.
\end{abstract}

Descriptors: Mandibular Fractures; Fracture Fixation; Molar, Third.

Resumo

A remoção do terceiro molar inferior corresponde a um dos procedimentos mais comuns na cirurgia oral. A extração pode resultar em várias complicações intraoperatórias ou pós-operatórias, especialmente quando os molares totalmente impactados estão envolvidos. Este relato de caso descreve uma fratura do ângulo mandibular após a tentativa de remoção de um terceiro molar inferior totalmente incluso de um paciente masculino de 41 anos de idade. A fratura ocorreu durante a mastigação, 3 dias após a falha na extração do dente 38 feita por um cirurgião dentista. Vários fatores que influenciam a possibilidade de fratura, incluindo sexo, idade, posição dentária e angulação, foram revistos e associados à lesão. Uma linha de fratura na região do ângulo da mandíbula foi observada na abordagem radiológica e tomográfica e foi essencial para realizar o diagnóstico. A abordagem de tratamento de fixação interna por redução aberta foi realizada para garantir a melhor recuperação do paciente. Conclui-se que a dificuldade em manter uma dieta leve e o fator de dentição completo, poderia ter sido determinante para causar a fratura.

Descritores: Fraturas Mandibulares; Fixação de Fratura; Dente Serotino.

\section{Resumen}

La remoción del tercer molar inferior corresponde a uno de los procedimientos más comunes en la cirugía oral. La extracción puede resultar en varias complicaciones intraoperatorias o postoperatorias, especialmente cuando los molares totalmente impactados están involucrados. Este relato de caso describe una fractura del ángulo mandibular después de la remoción de un tercer molar inferior totalmente impactado de un paciente masculino de 41 años de edad. La fractura ocurrió durante la masticación, 3 días después de la falla del intento de extracción del diente 38 hecha por un cirujano dentista. Varios factores que influencian la posibilidad de fractura, incluyendo sexo, edad, posición dental y angulación, se revisaron y se asociaron a la lesión. Una línea de fractura en la región del ángulo de la mandíbula fue observada en el abordaje radiológico y tomográfico y fue esencial para realizar el diagnóstico. El enfoque de tratamiento de fijación interna por reducción abierta fue realizado para garantizar la mejor recuperación del paciente. Se concluye que la dificultad en mantener una dieta ligera y el factor de dentición completo, podría haber sido determinante para causar la fractura.

Descriptores: Fracturas Mandibulares; Fijacíon de Fractura; Tercer Molar.

\section{INTRODUCTION}

Removal of lower third molar corresponds to one of the most common procedures in oral surgery. The extraction can result in several intraoperative or postoperative complications, especially when fully impacted molars are involved ${ }^{1-8}$. Mandibular angle fracture is the most serious complication following lower third molar removal, however, it's incidence is very low.

The literature reports indexes lower than $0.005 \%$ for mandibular fractures which $22 \%$ occurring during the surgery and $78 \%$ in the postoperative period ${ }^{6}$. Several variables may be involved in the increased frequency of postoperative mandibular fractures. The multifactorial risk factors include age, sex, dentition, third molar position and angulation, and other patient conditions ${ }^{2}$. The diagnosis is based on clinical and radiologic evaluations. In most cases, the fractures lines are difficult to be identifiable in the radiological approach, therefore, the suitable clinical appraisal should be performed carefully ${ }^{9}$. Patients usually come to clinic 1 to 3 weeks following the third molar after hearing a crack sound while chewing ${ }^{10}$.

The main current and conservative treatment to manage mandibular angle fracture is the soft diet. However, in more severe cases open reduction internal fixation and intermaxillary fixation approach might be necessary to restore patients oral health ${ }^{11}$. In this study, we present a case of late mandibular fracture after third molar extraction attempt, evidencing its treatment.

\section{CLINICAL CASE}

A 41-year-old male patient attended at Santa Casa de Araçatuba complaining of alveolar inferior nerve paresthesia of the left side after attempted exodontia of the non-successful element 38. After 3 days of the surgical procedure when feeding, the 
patient heard a cracking noise in the region of the left mandibular angle and immediate occlusal alteration to the noise. The patient denied systemic alterations and he reported being allergic to dipyrone. On physical examination, edema was observed in the region of the left mandibular angle, limitation of the buccal opening, crepitation on palpation in the region of the left mandibular angle, and sutures in the position of the surgical procedure for the extraction of the element 38. Computed tomography showed the presence of element 38 in class II, position C according to the Pell and Gregory Classification ${ }^{12}$, and position mesio-angular according to the Winter classification (Figure 1), and fracture line associated with the dental element (Figure 2).

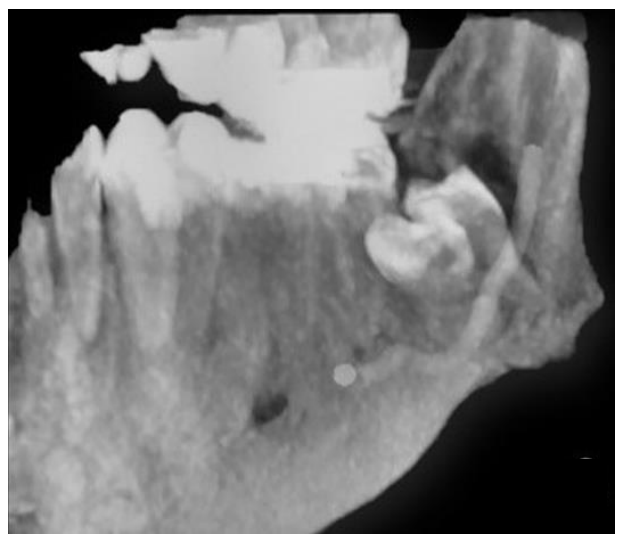

Figure 1: Preoperative panoramic view of tooth and line of fracture associated (computerized tomography).

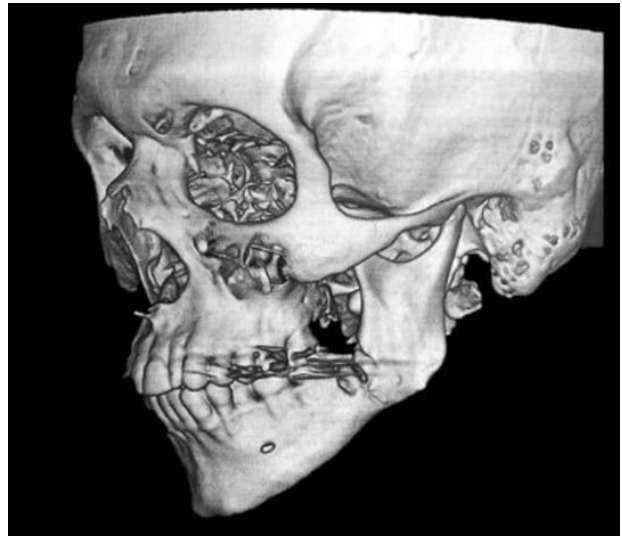

Figure 2: Preoperative 3D reconstruction showing the angle fracture (computerized tomography).

The surgical treatment for element 38 extraction followed by the reduction and fixation of the fracture was stipulated. General anesthesia with nasotracheal intubation was performed. The anesthetic infiltration of bupivacaine hydrochloride associated with epinephrine in a ratio of 1:200,000 in the left mandibular vestibular fundus. Access was made by a mucoperiosteal incision with a relaxing incision, followed by mucoperiosteal detachment to expose the dental element and the fracture line. For the exodontia, an odontosection was performed on the vestibulo-lingual direction (Figure 3), followed by the removal of the mesial portion and posteriorly the distal portion (Figure 4).
Subsequently, maxillo-mandibular block was performed to stabilize the occlusion and correct fracture reduction. The fixation was performed through an 8-hole plate of the 2.0 system with the Champy method ${ }^{11}$ (Figure 5). Finally, the flap was repositioned, and the suture was performed with vicryl 4-0 and nylon 5-0. The postoperative CT showed de good placement of the plate and screws (Figure 6) and right reduction of the fracture (Figure 7). In the postoperative follow up of 4 months the patient does present a good evolution and absence of complaints or complications.

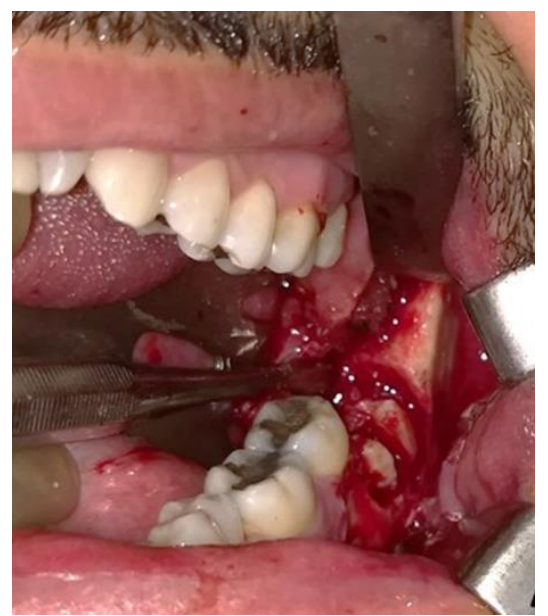

Figure 3: Surgical procedure of osteosynthesis of the mandibular angle: exposure of the fracture and odontosection of element 38 .

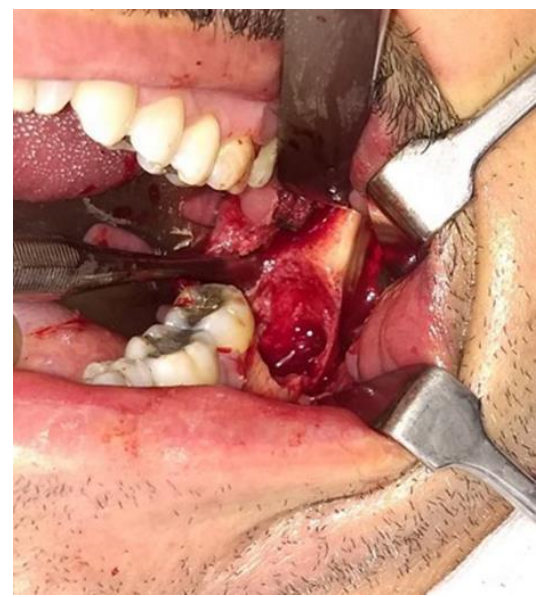

Figure 4: Surgical procedure of osteosynthesis of the mandibular angle: exodontia of third molar and exposure of line of fracture.

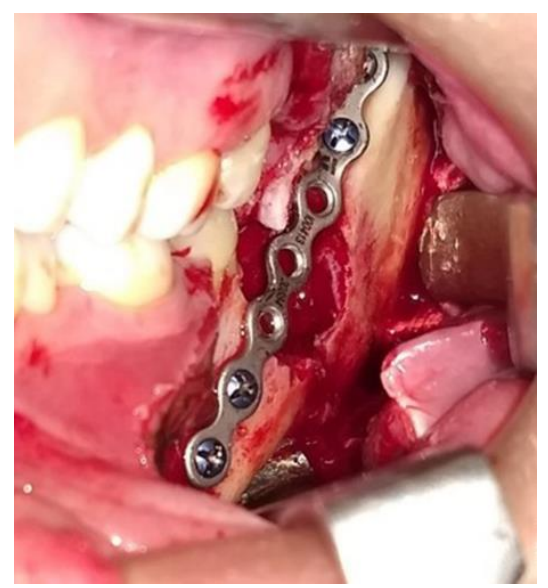

Figure 5: Fixation of mandibular angle fracture by Champy method with 1 plate with 8 -holes and 5 screws of 2.0 system. 


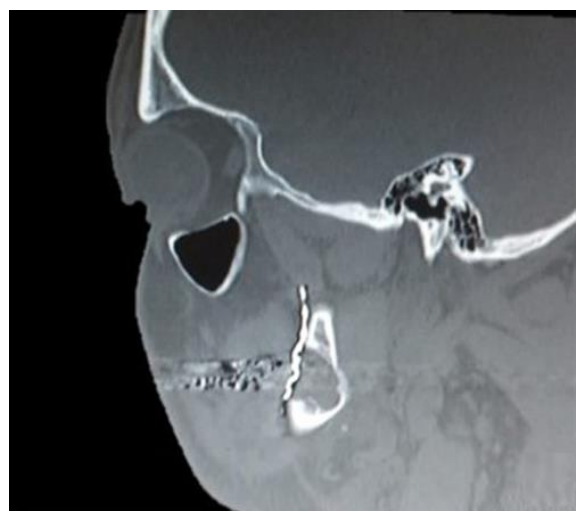

Figure 6: Sagital view showing the good placement of the plate and screws of 2.0 system (computerized tomography).

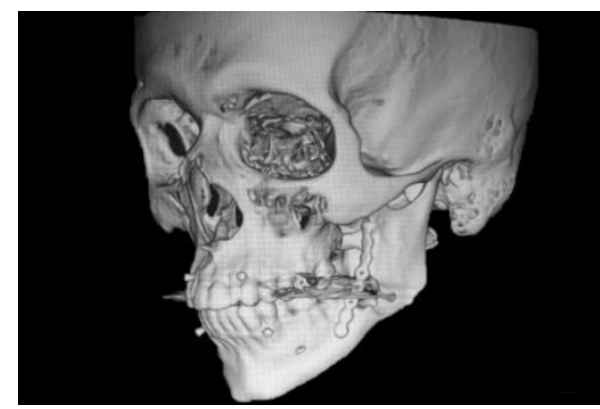

Figure 7: Postoperative 3D reconstruction showing de right reduction that is evidenced by the correct placement of mandibular base, obtained by Champy method (computerized tomography).

\section{DISCUSSION}

Removal of the lower third molars is a very usual approach in oral surgery. The pathological postoperative fracture of the mandibular angle is uncommon but granted complication afterward third molar extraction. Several variables including age, gender time, dentition, third molar position and angulation and pre-existing patients' conditions (infections and cystic lesions) have been cited in the literature as risk factors in the fracture occurrence ${ }^{1-8}$. Some of these factors may have implicated to the lesion in our patient.

First, taking into account that the majority of patients that undergo a third molar removal surgery is adults between, most cases presented in the literature report more incidences in this age group. In this present case, the patient's age ${ }^{41}$ and gender (male) could be deeply related to the emergence of fractures in the angle of the mandible $e^{2,4,10}$. The stronger masticatory muscles in males may have a crucial impact in the biting force and consequently in the incidence of mandibular angle fracture after third molar removal. Besides, men lifestyle may also be determinant in postoperative fractures ${ }^{1,9}$. Males are more prone to be involved in traffic and sports accidents. In this context, gender appears to be a significant factor in the injury emergence in the postoperative period $^{13,14}$.

In relation to the event period occurrence, the fractures may be divided in the intra-operative, as an instant complication during surgery, or postoperative, when a late complication occurs, usually among 1 day to 8 weeks. In our case, the patient's mandible was fractured 3 days following tooth removal. It is during this period that the granulation tissue is being formed to be replaced, later, the connective tissue in the extraction zone, which could explain the increased risk of fractures ${ }^{4,15}$.

Besides, it is common for patients after this period of time fail in the recommended soft diet ${ }^{6}$. In addition, once the discomfort related to the surgery has ceased after some days, patients do not avoid chewing in the extraction site. Therefore, the masticatory forces directed towards the susceptible bone might be sufficient to emerge the injury ${ }^{1}$. In this case, the patient visited the hospital reporting hearing a characteristic crack sound in the mandibular region while eating and complaining of alveolar inferior nerve paresthesia of the left side.

In this context, our patient also presented full dentition, important factor in the emergence of mandibular angle fractures. Studies conducted by $\mathrm{Krimmel}^{8}$ revealed that regardless of gender, patients that had full dentition were more prone to be affected. In this scenario, the maximal occlusal forces are transmitted direct to the injured bone and hence increasing the risk of fracture ${ }^{16}$.

Patients with complete dentition are able to produce maximum levels of bite forces, which are transmitted to the weak jaw during chewing and, consequently, the risk of fracture is high regardless of sex. However, for Miyaura et al. ${ }^{17}$, the biting force of men in relation to the female tends to be greater.

The third molar impaction degree is also a significant factor. Lower molar location and angulation appear to be the main responsible for the risk of mandibular angle fractures ${ }^{4,10}$. Fully impacted third molars proportionally occupy a greater volume of the mandibular bone, consequently, a significant amount of bone may need to be removed during surgical extraction, weakening the mandible ${ }^{18}$. In this study, the patient presented the combination of class II and $\mathrm{C}$ in the classification proposed by Pell and Gregory $^{12}$ resulting in an extensive osteotomy, which is quite frequently associated with angular fractures. In respect to the inclination, the Winter classification in mesio-angular, horizontal/ vertical and distoangular impactions may be considered to be gradually trickier in relation to the third molar extraction and complications in postoperative recovery. In the present relate, the patient presented the tooth positioned in mesio-angular inclination, corroborating with Ethunandan et al. ${ }^{10}$ studies, where the mesio-angular inclination was found to be the most frequent $(32.06 \%)$ in a study involving 130 cases from 1970 to 2011. Although pre-existing bone lesions, such as cysts, periodontal diseases, and others may also play an important role in fracture development $^{6,10}$, our patient did not present any previous condition.

Suitable diagnosis is required to establish 
appropriate treatment and prognosis. Therefore, the clinical and radiologic approach may be used as methods to evaluate postoperative mandibular fracture. Although in most cases the fractures lines are difficult to recognize in radiologic images, these lines were clearly identifiable on panoramic radiographs ${ }^{9,15}$. In the present study, the imaging diagnosis was performed by computed tomography (CT), due to the availability of the apparatus in the hospital's premises.

The main objectives in the treatment of mandibular fractures are to restore the mandibular contour, dental occlusion, and temporomandibular joint function ${ }^{4,19}$. Different modalities are currently used to treat mandibular angle fracture. In most cases, a soft diet is used as a conservative alternative to manage patients with favorable prognosis. On the other hand, open reduction internal fixation and intermaxillary fixation approach have also been used in more complex cases ${ }^{11}$.

\section{FINAL CONSIDERATIONS}

In our case, general anesthesia with nasotracheal intubation was performed. The intraoral incision to expose the mandible fracture line was necessary due to the injury extension. Subsequently, maxillo-mandibular block was accomplished to stabilize the occlusion and correct fracture reduction. The fixation was performed through an 8-hole plate of the 2.0 system with the Champy method, employed to promote the anatomical reduction of the fractured bone and immobilization to allow correct bone consolidation.

\section{REFERENCES}

1. Al-Belasy FA, Tozoglu S, Ertas U. Mastication and late mandibular fracture after surgery of impacted third molars associated with no gross pathology. J Oral Maxillofac Surg. 2009; 67(4):856-61.da

2. Bodner L, Brennan PA, McLeod NM. Characteristics of iatrogenic mandibular fractures associated with tooth removal: review and analysis of 189 cases. Br J Oral Maxillofac Surg. 2011;49(7):567-72.

3. Bouloux GF, Steed MB, Perciaccante VJ. Complications of third molar surgery. Oral Maxillofac Surg Clin North Am. 2007; 19(1):117-28.

4. Joshi A, Goel M, Thorat A. Identifying the risk factors causing iatrogenic mandibular fractures associated with exodontia: a systemic metaanalysis of 200 cases from 1953 to 2015. Oral Maxillofac Surg. 2016;20(4):391-96.

5. Libersa P, Roze D, Cachart T, Libersa JC. Immediate and late mandibular fractures after third molar removal. J Oral Maxillofac Surg. 2002;60(2):163-66.
6. Perry PA, Goldberg MH. Late mandibular fracture after third molar surgery: a survey of Connecticut oral and maxillofacial surgeons. J Oral Maxillofac Surg. 2000;58(8):858-61.

7. Pires WR, Bonardi JP, Faverani LP, Momesso GAC, Muñoz XMJP, Silva AFM et al. Late mandibular fracture occurring in the postoperative period after third molar removal: systematic review and analysis of 124 cases. Int J Oral Maxillofac Surg. 2017;46(1):46-53.

8. Krimmel M, Reinert S. Mandibular fracture after third molar removal. J Oral Maxillofac Surg. 2000;58(10):1110-12.

9. Wagner KW, Otten JE, Schoen R, Schmelzeisen R. Pathological mandibular fractures following third molar removal. Int J Oral Maxillofac Surg. 2005;34(7):722-26.

10. Ethunandan M, Shanahan D, Patel M. Iatrogenic mandibular fractures following removal of impacted third molars: an analysis of 130 cases. Br Dent J. 2012;212(4):179-84.

11. Ellis E 3rd. Management of fractures through the angle of the mandible. Oral Maxillofac Surg Clin North Am. 2009;21(2):163-74.

12. Pell GJ, Gregory GT. Report on a ten year study of a tooth division technique for removal of impacted teeth. Am J Orthodont Surg. 1942; 28:660-71.

13. Antoun JS, Lee KH. Sports-related maxillofacial fractures over an 11-year period. J Oral Maxillofac Surg. 2008;66(3):504-8.

14. Chrcanovic BR, Custódio AL. Considerations of mandibular angle fractures during and after surgery for removal of third molars: a review of the literature. Oral Maxillofac Surg. 2010; 14(2):71-80.

15. Iizuka $\mathrm{T}$, Tanner S, Berthold $\mathrm{H}$. Mandibular fractures following third molar extraction. A retrospective clinical and radiological study. Int $\mathbf{J}$ Oral Maxillofac Surg. 1997;26(5):338-43.

16. Woldenberg Y, Gatot I, Bodner L. Iatrogenic mandibular fracture associated with third molar removal. Can it be prevented?. Med Oral Patol Oral Cir Bucal. 2007;12(1):E70-2.

17. Miyaura K, Matsuka Y, Morita M, Yamashita A, Watanabe T. Comparison of biting forces in different age and sex groups: a study of biting efficiency with mobile and non-mobile teeth. J Oral Rehabil. 1999;26(3):223-27.

18. Bezerra TP, Studart-Soares EC, Pita-Neto IC, Costa FW, Batista SH. Do third molars weaken the mandibular angle?. Med Oral Patol Oral Cir Bucal. 2011;16(5):e657-63.

19. Grau-Manclús V, Gargallo-Albiol J, AlmendrosMarqués N, Gay-Escoda C. Mandibular fractures related to the surgical extraction of impacted lower third molars: a report of 11 cases. J Oral Maxillofac Surg. 2011;69(5):1286-90. 


\section{CONFLICTS OF INTERESTS}

The authors declare no conflicts of interests.

\section{CORRESPONDING AUTHOR}

\section{Rodrigo Capalbo da Silva}

José Bonifácio Street 1193, Vila Mendonça

16015-050, Araçatuba, São Paulo, Brazil

Phone: +5518 3636-2898

e-mail capalbo.rodrigo@gmail.com

Received 02/05/2019

Accepted 28/08/2019 